\title{
Evaluation of the Significance of Self-Visionary Writing based on the Fieldworks of Querencia and Independent Bookstore
}

\author{
Myoung Hee $\mathrm{Yi}^{1}$ \\ ${ }^{1}$ Professor, Sang-hug Liberal Arts(s), Kon Kuk University, Korea, newyorkmago@hanmail.net
}

\begin{abstract}
The purpose of this study is to investigate how 'Creative Thinking and Writing' class with related field activities develops and motivates self-expression skills of $Z$ generation students during the COVID-19 pandemic compared to traditional liberal arts writing class which has been an edited knowledge-based. A writing class, as part of basic liberal arts education in university, has been considered as a non-interested requirement by the students and the productive outcome for the students has been minimal. The class was designed to produce proactive involvement by the students in order to motivate a creative and self-awareness writing experience and to be expanded to designing self-visions. For the study, the class was conducted with a total of 142 students in spring semester of 2021, including 17 students in summer session, with a survey conducted at the end of the class. The class was designed and planned in consideration of digital-oriented $\mathrm{Z}$ generation, adding fieldworks so that the students were able to focus more on self-narrative. As a result, the students were able to experience selfawareness from the benchmarking of commercial introductory writing to self-visionary writing. The students also found how to start expressive writing with less difficulty after reviewing their own querencia and "Habitus." The survey indicated that $28 \%$ of the students registered the class because it had fieldwork projects and $73 \%$ agreed the class as helpful for improving their creative writing skills. 84 out of 125 said that the fieldworks initiated the writing without any difficulty. However, because the class was not able to distinguish between science and liberal arts students, it was not designed for each discipline's approach. A separate class design per discipline and converged education scheme were needed to be improved. In conclusion, the study indicated that the class supported a positive impact on self-expressive writing through self-learning and voluntary participation by self-selecting a subject and field of interest. The fieldworks functioned positively by reflecting the desire of self-revelation by $\mathrm{Z}$ generation students. A self-narrative with the fieldworks delivered a strong context by the writer configuring an objective self-vision. A significant progress on skills of self-searching, self-expression and creative organization was manifested and the class provided proactive writing initiatives. From the class evaluation, $89 \%$ said that the class motivated them to search further about oneself and life designing afterward. This explained the positive impact not only on academics but also on the campus life of the students.
\end{abstract}

Keywords: Field Work, Self-vision, Creative Writing, Querencia, Pandemic, Independent Bookstore, Habitus

Received: June 23, 2021; $1^{\text {st }}$ Review Result: August 10, 2021; $2^{\text {nd }}$ Review Result: September 25, 2021 Accepted: October 31, 2021 


\section{Introduction}

The education scheme under pandemic has been changed from in-class to off-class via online platforms, creating an absolute need for multi-dimensional class activities and educational methods. Knowledge can only be completed knowledge when fragmented information in social context is collected and interpreted. The students of $Z$ generation in 'new normal' era caused by COVID-19 need an obligation and mission to reinterpret a new environment with the existing knowledge system. Acquiring knowledge from disciplines of the university is always insufficient for the students in this system. And to make matters worse, the established educational culture of the intellectual community has difficulty transferring to student with online classes. It has become impossible to conduct a customized class by each discipline, and active discussions and experiments are no longer possible. Coherent thoughts and extensive research as of intellectual community are no longer possible. Additionally, the utilization of new media platforms in the university is far less than any other sector due to the characters of lecture and research focused of the university. The mutually satisfied factors of class progress between the students and professors are about to collapse. An introspection of education community is necessary for the era. This 2021 study of 142 students of creative writing class evaluated the impact to $\mathrm{Z}$ generation students in pandemic through different format of fieldworks projects correlated with self-visionary and self-expressive writing. It also evaluated an improvement of students' attitudes from a traditional writing to self-inflicted participation of expressive and creative writing suited for $\mathrm{Z}$ generation. The fieldwork projects were designed in consideration of $\mathrm{Z}$ generation characteristics. The difference of $Z$ generation from $X, Y$ and $M$ generation is that 'they are more comfor with SNS, mobile \& internet environment living in the digital world'[1]. Social media activities by Z generation are automatically interlinked with their special ability for self-focused writing - therefore, the class re-focused this specialty with self-visionary and expressive writing projects in a mandatory basic course of writing class in order to make easier for the students to start writing. The class was also designed to generate the interest with self-awareness opportunity when the class forced them to think about the future. The purpose of this study is to evaluate the improvement of creative and self-visionary writing through fieldworks, as well as the improvement of expressive writing, which is responsible for general writing in basic liberal arts education. The class assured that the students focused more on proactive and voluntary writing rather than traditional steps of reading, research and writing of previous writing classes.

\section{The Design of the Class}

The 'Creative Thinking \& Expression' class, is one of the mandatory liberal arts classes in Kon Kuk University with an objective to understand various information and knowledge to build creative communication ability. The students were focused on 'self-expressive writing' in 4 weeks accompanied with the fieldworks of querencia and independent bookstore to design a creative self-vision, which was followed by a self-visionary writing. The class offered 3 separate writing projects and an individual presentation. 1. A self-introduction to the readers. The fieldwork to the independent bookstore was required to find a book to benchmark a commercially viable writer's introduction. 2 . An essay of 1 or 2 pages of self-introduction after they found an individual querencia by the fieldwork. The essay had to have the meaning of the space as querencia where they selected and a self-expressive writing to the target readers. Findings of individual "Habitus" and negatives, and how to overcome them, were also included in the essay. 3. A self-visionary essay was assigned after reviewing future professions of interest correlating with previous writings.

The purposes of the class design are as follows. 
1) First, the independent bookstore fieldwork was designed to provide an experience to the students in which they could imagine their future career paths and to motivate them to write an introduction as a fun imagination of being an author of a book without any limitation. And it offered an assignment to do a self-expressive writing by benchmarking commercially viable author's introductions.

2) Second, the class was assigned to write a vision and a mission by the querencia fieldwork after evaluating negative aspects from the past to present in order to become who they want to be in the future.

The 'Creative Thinking \& Expression' class was conducted with a total of 142 students including 125 in regular semester and 17 in summer session as a mandatory liberal arts credit course in Kon Kuk University in 2021 with an objective to write 3 separate writing assignments related to self-vision development with 2 fieldworks projects. The fieldworks with 3 writing assignments are as follows:

1) Find a book of interest and benchmark the author's introduction in order to write their own introductions as being an author of their future published books after their visit to independent bookstore.

2) Find their own querencia to think about their habitus in order to write a true expression of themselves.

3) Interlink previous 2 assignments to write a self-visionary design of their future after a careful review about their disciplines and what they wanted to do in the future.

For the self-expressive writing, the students needed to spend time to think about who they were, what they wanted and what kinds of habits they had. Z generation[2] tends to be more interest focused but most likely spends more time on other people's writings on the internet, and therefore a lack of selfawareness is comparatively greater. The class was designed to focus more on a self-focused writing by empirical learning such as fieldworks after selecting their own interests from a search. It was because of lack of contextual organization skills due to a near addiction of short text generated by social media platforms. With a consideration of different interest level by disciplines, 'independent bookstore' visits were designed over franchise bookstores to select commercial books. 'Independent bookstores' differed from franchise bookstores in that students were able to have analog experiences by having a recommendation or selection by owner's personal preference[3]. The students' focus when selecting a book was on the author's profile introduction located on a flap of the book. A commercially viable introduction of the author was a requirement later in the class as a creative self-introduction.

\subsection{The Fieldwork of Independent Bookstore and Book Flap Self-introduction}

One of the characteristics of $Z$ generation is to be an influencer and lecturer. This fieldwork gained a particular interest among the students because it amplified the needs to be an influencer and lecturer. The bookstore fieldwork supplied new interests of spaces to design for architecture students and it also provided insights to liberal arts students. It also provided new experiences that were never exposed to engineering and science students. The other advantage was to have the experience of effective selfintroduction writing by being exposed large quantity of books for a short period of time. The class was designed to have the keywords selected by self-searching of a particular subject of interest throughout the course. The student had to write a detailed essay of why the independent bookstore was selected and what kind of valued experience was gained.

Creative thinking usually manifests through organizing one context from non-related multiple keywords. The students were led to focus on how to write a short but impressive self-introduction on a book flap of their own after selecting commercially viable introduction piece because it was not different from the social media writings The most important aspect of a book flap writing was to write a distinctive and creative self-introduction that was different from a resume. The process of self- 
discovery and learning while benchmarking successfully published and marketed books in the market was a critical aspect of the class. Their writing was designed through feedback sessions so that the students were able to learn whether their selections and writings were effective to the target audience. The class guided the students to revise the draft after applying the feedback from the audience.

Following are the examples of revised writing after feedbacks.

[Table 1] Examples of Book Flap Writing after Independent Bookstore Fieldwork

\section{PARK OO/ English Literature Major/ Freshmen}

<Revised of Book Flap Writing after Feedbacks>

She is a member of DSB (Dispute Settlement Body) in WTO and has $\mathrm{PhD}$ on international trade. Graduated from Kon Kuk University in English Literature and has a M.A. on International Trade. The author started her career in UN HCR to support $3^{\text {rd }}$ world countries and is active in WTO to fight against the tariff war which was her original objective. She has published many research papers including [Research of US-China Trade War: Evaluating Biden's Policy on China Tax.] She is also active on free trade with APEC in Asia Pacific and consequently the book steps through a stream of world trade from her experience of working with trade organizations over the last 5 years. <Cross Pacific Merchant> with her opinion on minimizing trade limitations for international stability steers our journey to trade resolutions in the post pandemic.

With a vague adoration for UN organizations, she grew her dreams as a child looking at a UN Secretary General BAN and a Head of Trade and Negotiation Headquarters, YOO Myung-Hee. She took a real step toward the world when she became an adult. With a regret of late enactment of her dream, she is now coaching future talents with her < Research Institute of World Trade>.

\section{$<$ Revisions>}

I focused on $2^{\text {nd }}$ and $3^{\text {rd }}$ paragraphs to revise. I tried to add more introduction of author and details of economy recovery as professor's feedback. I have added a personal opinion on economy recovery in front of the title of the book and also added future organization after deleting a final objective. In addition, I have changed to scythe symbol instead of a quotation mark for the paper indicated on paragraph 1 and tried to have entire work experience in the front. It looks more of an author introduction than an autobiography with an objection because of professor's feedback.

\section{PARK OO/ Cultural Contents Major/ Freshman}

<Revised of Book Flap Writing after Feedbacks>

(I am a 35 years old theater director and YouTuber. I wrote this book after finding my observational journal from my college days while cleaning my room. This books is about my thoughts on the value of imagination with back stories of my work, such as short stories and introduction of characters that motivated my theater pieces.)

Majored in Cultural Contents in Kon Kuk University, the author directed <KIM Hyun Sub Biography> <City Dorothy> and others as a Theater Director of 'DaySoldOut.' He is also a YouTuber with a million subscribers featuring making films of his plays. I would love to be introduced as 'a creator of theater consumer platform $<$ DaySoldOut $>$ ' which is a center of a theatrical art resurrection against YouTube in 2023. I am making theater plays but I am still nobody who likes to kickback and chuckle at somebody else's work. I am an absolute dreamer and romanticist. I fantasized building a cookie house lasting forever as a child but when my taste of cookie changed, I changed my dream to make a play with my cookie house fantasy. I am still imagining a fantasy world and happy trying to make it real. Sometimes, daydreaming is not considered a very positive activity but it is pretty fun to live as a dreamer. In fact, daydreaming is my biggest motivation of what I do. I often heard from people around me that I was having fun at work or school. I sometimes took a memo whenever a fun story came to my mind after observing lots of people and imagining what they do or what stories they would have. My play <KIM Hyun Sub Biography>, which still plays every $6 \mathrm{pm}$, was started from my memo. As such, day dreaming could be a big motivation to make it real. I love to talk to as many people as possible on how to make imaginations real, because one of my biggest goals is to make people happy with my imagination. I would love to be a realistic day-dreamer to show that a day-dreamer can exist in the real world.

\section{<Revisions>}

1. Repeating of 'I' is eliminated. 2. Summarized explanation of <DaySoldOut> in intro. 3. Focused on 'person introduction' to make it less of a prologue or cut out of some part of the book. It was hard to show without an explanation of the book why the book should be read and what relations with the book and the author as a day-dreamer. So it changed to an author's perspective on what he earned from his daydreaming. 4. 'Scribble' and other words was cut off for the author's credibility. 
As above the examples show, the students were motivated to have better readability through feedback. Both example 1 and 2 reflected the context of their writing and output with a consideration of reader's readability. The students were able to find how to attract the readers through benchmark of other author's introduction that matched with their interests from the fieldwork of independent bookstores. They learned the power of writing with contextuality from the readers when individual's subjectivity and holism were gathered[4]. The fieldwork had its significance when the students could express what they wanted by mirroring 5 senses from the fieldwork of their own interests.

\subsection{Querencia Fieldwork and Narrative Writing}

Alfred North Whitehead insisted that 'Education is the acquisition of art of the utilization of knowledge,' and emphasized utilization aspects of the education. 'Utilization' in this case is a related concept to a response of individual's creativity. In other words, it is the utilization of a certain concept connected with other concepts (or different experiences) attached with key interests[5]. From this context, the class needed to teach the student to understand the relations of existing individual experiences, and to configure a project that defines these relations as a meaningful philosophy. The querencia Fieldwork was to guide the students to design a self-vision from their individual experiences. Querencia means a space for a bull to be strong and safe in a bullfighting ring in Spanish. It currently refers to a place that people could get away from daily stresses to refresh and recharge their mind and body these days[6]. Querencia has become one of the popular words among Z generation in connection with one of the marketing trends when it was selected as a keyword of consumer trend in 2018. Some $\mathrm{Z}$ generation who tend to stay home with boundaries of their own have made querencia as a unique place where they can prepare their healings and survivals. Some others of $Z$ generation have opposite behaviors. They tend to look for a sanctuary in hot $\&$ trendy places in order to get validated by others and use it as a safe house or a shelter to prepare for the future. However, the class did not introduce the querencia as just a passive healing place when selecting it as a keyword to write a self-visionary narrative. The class required a self-visionary narrative from self-awareness with a keyword 'querencia' regardless of the preference in which the querencia no longer meant of a passive healing space to the students. The class offered sequential projects to make the students aware and prepare for a creative visionary self-design, in addition to research on their future career in order to complete the course of self-expressive writing. It was essential to make the students recognize that the querencia fieldwork for self-introduction of book flap were a part of the course to complete their self-expressive writing. The class recommended a time for self-awareness to find querencia where the students felt comfortable and to be creative after thinking about their future. The students then organized their thoughts on macro and micro objectives to eliminate their possessed habitus. Habitus is a concept suggested by a French sociologist Pierre Bourdieu and is considered as a 2nd instinct derived by socio-cultural environment[7]. Doris Martin looked habitus as more fundamental concept than a habit. The students were required to have more attached experiences on self-visionary design after reviewing their own habitus in querencia where they selected as a space for healing and comfortable.

Below is a writing of a freshman in the class. This entire writing demonstrated a process of how one's issue was dealt after the querencia fieldwork by a film major student who did not experience a campus life due to the pandemic. 
[Table 2] An Example of Student Writing on Querencia Fieldwork

BAE OO Querencia / Visual Film Major / Freshman.

1. A place came to my mind as soon as I heard querencia. It was a bicycle road next to Nakdong river near my old home. I visited the road to clear my mind whenever I felt down stuck in the house. I felt comfortable on this road after spending more than 15 years walking down the road with friends, family and sometimes alone. I decided to visit there using this class activity even though it was far from my home now. I was thinking what kind of person I was when I walked down the road. I was like a main character in a cartoon called Crayon Shinchan when I thought about my personality - vivid, quirky and positive. And I could add some other characteristics such as giving up easy, not focused and not enduring. 'Me?' and 'no way' were the words coming to my mind whenever I tried to do something. This was my habitus. I jailed myself in a frame called 'lightness.' I deeply thought about how to make it better. Then I had a phrase from 'Miracle Morning' by Hal Elrod in my mind. It said that you became someone when you tried to be like someone else. I looked up for any great person as my role model. But I decided not to have just one, but many, whenever I needed a character to resemble and to change for a different occasion.

2. So what is my micro and macro objective to be? If I watched my dream as a big forest, I want to be an ethologist expert as a sociology perspective. To achieve this, I realized that I might need some trees to make a forest which would be graduating college with high GPA, getting various certifications and so forth. And I also might need hundreds of branches in the tree like preparing for midterms, focusing on lectures and being better at English. My other objective is to be a 'genuine person'. I would like to make the best of my choices rather than contemplating what to choose in many crossroads. It would be best if someone chose me as a role model. In one sentence, I would like to be a person who tries best for myself. I made a to-do list with some objectives, such as keep my posture right, no long hours on my cell, be confident and do what is planned. I promised myself to get up at 7 every morning and check my to-do list before bed. I came back to Seoul and walked next to Han river remembering a walk on the bicycle road next to Nakdong river. It gave me a lot of thoughts and motivation to change. Nakdong river was my past that was comfortable, relaxed and dark. Han river today is busy, vivid, wide and new. I felt cozy from the familiarity and excitement from the change when I thought of Nakdong walking next to Han river. I thought that I needed to change as my surroundings were changed as well. I thought about making a new 'me' disconnecting from my past habitus.

3. But I had to face myself - one who does not change immediately despite my own determination. I thought about a butterfly from a caterpillar. It needed to have a time to endure as a cocoon to be a butterfly. Even a small cell had a longer interphase than cloning. Then I suddenly started to like the word 'Preparing' in my chain of thoughts. I felt clear that the moment could be as a cocoon or interphase no matter how painful, hard and lonely. I felt cool about myself enduring a process to get away from my familiarity after recognizing what was clear and what was not.

4. I experienced reality doing a part-time job after I was done with my high school entrance exam. I was fired after only 3 hours. It gave me big trauma. I had a thought that the world only wanted a complete person after the experience, and it naturally led to disappointment and fear the world thought of me as incomplete. It was the first time I had an alertness toward the world. Eventually, due to my trauma, I was able to overcome a fear of getting a no and had an ability to have courage from nowhere. A cocoon called 'trauma' had become a butterfly called 'change.' People said 'enjoy it if it were unavoidable.' It could be hard to accept my changes but it was a meaningful time to accept it as pain if the cocoon was indeed a part of me in order to complete me. I found the habitus that I covered by myself with from the querencia fieldwork, and remembered how I won over it. I now had courage after I faced my change. My habitus would be gradually changing as my querencia changed to Han river from Nakdong.

Above example showed that a natural progress of narrative was developed in steps from 1 to 4 . After the project was given, the writer decided to have her old home as her querencia and she thought about herself in that comfortable space for the first time. As it showed in the survey of awareness level between the fieldwork and self-expressive writing [Table 3], the writer took the project as 'a time to have a genuine search of herself' or 'a time to think about only herself using the querencia fieldwork.' In order to do so, the students had to recognize an importance of thoughtful research and selection. Given the pandemic situation, the students needed to have enough spare time to do the fieldwork and the pictures of the fieldwork and memo were supposed to be submitted as a class assignment at the time of lecture and attendance.

The writer focused herself with a keyword as 'her habitus' in \#1. In \#2, she set up vision from her todo list to a macro objective as 'a person who tries best for myself.' The writer then revisited her determination when she came back to her querencia facing reality in Han River. Her vision led to a 
mission statement adapting a law of nature as 'a butterfly from a cocoon' and faced fully without rejecting herself. As it was shown in \#4, the writer found the habitus that she covered herself with in the past and revisited her experience overcoming her habitus. As she wrote as 'a courage came after she faced her changed self,' the project showed a close reflection of how self-awareness could come from the fieldwork and writing experience.

\section{The Significance of Relationship between the Fieldwork and Self-expressive Writing}

A creative self-expressive writing class was conducted during the summer semester as the regular semester. It could be stressful for both professor and students due to daily classes during the summer class comparing with the regular semester. Nevertheless, the survey indicated that the fieldwork worked significantly on self-expressive writing to the students. 5 questions were given to 16 students. As for a preference of the fieldwork category, a total of 4 questions were given to analyze the relationship between the fieldwork and self-expressive writing along with a short answer question.

First, all 16 answered yes to the question of 'Do you think that self-introductory writing is necessary in college liberal arts course?' This showed that the students recognized the writing as an asset for their academic researches including practical writing for a self-improvement. Second, 15 out of the 16 students answered yes to the question of 'Do independent bookstore \& querencia fieldworks and creative self-vision design help for self-expressive writing?' Short answers showed what kind of support they had in which area. Third, all 16 answered yes to the question of 'Do the fieldworks of independent bookstore and querencia help for self-visionary writing?' It showed that writing after the fieldwork could be a strong motivation for proactive writing, and short answers by the student supported this. Below is the summary of short answers by the students.

[Table 3] Survey of the Fieldworks and Self-expressive Writing (Total 16 Students)

\footnotetext{
A book flap writing instead of a simple self-intro writing made me look deeply about myself.

It was quite meaningful time to look fully about myself during the class of book flap introduction and querencia project. A time to think deeply about myself is necessary but it would be hard to find a separate time as the project is.
}

Independent bookstore author introduction writing made me think about details of my future career and how to attract public's attention. The querencia fieldwork found my interest that was covered by habitus and it was helpful to find my dream.

The fieldworks of querencia and independent bookstore were helpful for my self-visionary writing because they gave me time for heavy thoughts about my future. It was an opportunity to think about myself during querencia and selfexpressive writing. and I thought about how to introduce myself during the fieldwork of independent bookstore. I had not thought about myself often but it was a huge value for me to find out about myself during the project. Heavy thoughts about my future and my major was an advantage.

I especially remembered the practice of getting rid of habitus in querencia project. It was helpful to set up my vision.

I experienced a connection between the keywords from media examples with ones I used in querencia and independent bookstore fieldwork while completing my writing for the last end of the semester project (creative career design). It was amazing. I definitely think that those 3 projects connected each other.

I was able to check the past and present and a future of myself during the book flap introduction. I am not sure of what querencia project meant to other students but I could have greater effort on future vision designs using querencia.

Querencia fieldwork was helpful due to a clear objective of self-awareness. I am not sure of the connection to vision design because independent bookstore fieldwork was rather recognized as cultural experience opportunity than selfawareness. 
I don't think that book flap introduction was helpful to me personally. When I was writing self-introduction, I could not express fully about myself because it was more focused on benchmarking of existing creative author introduction than expressing myself. However, it was very meaningful time for me to think deep about myself from the past to present during querencia fieldwork, and I was able to find answers to questions on my major to design my vision from it.

It might be meaningful to someone who has a space as querencia but I don't think most of the people would think about querencia.

Independent bookstore fieldwork was very much helpful in 3.3. It was worthwhile to see many examples in the independent bookstore with limited books rather than franchise bookstore. It was a good experience. The querencia fieldwork made me think about myself by defining regular places after after discovering my querencia. I was in despair when doing a research on vision design because I had no plan for the future or for a reality check. After checking my surroundings and comparing with reality, I had some regrets and frustrations. The class offered a vision design opportunity to solve these issues but I don't think I have a vision for myself. The class was very informative because this is an issue that you have to face someday.

My thoughts about myself during the fieldwork of independent bookstore and querencia aided for my search of career vision design.

I was able to look back of my life during the book flap writing after the fieldwork of independent bookstore and I was also able to recheck my objective doing querencia fieldwork.

Habitus checking and creative vision design was incredibly helpful for self-expressive writing through querencia fieldwork. But it was not helpful with independent bookstore fieldwork. Making my own book flap introduction was good for my self-expressive writing but the books that I had in independent bookstore were not good examples. A book flap writing and querencia fieldwork was very useful for creative vision design. I was able to draw a conceptual roadmap about my vision when writing my own introduction. I was also able to gain huge information about career path doing creative vision design project. In addition, it was good to have a clarification on 'how to find a career group for myself' when setting up a detailed plan. I had a firm determination after having self-awareness about distractions for my future plan by doing 'querencia fieldwork-habitus checking.'

It was a huge opportunity to go outside and do something meaningful. It was my first experience to visit an independent bookstore and it was also my first to visit querencia to look for myself. All these were new meanings as my first experience and was to widen my spectrum. I guess a time to think about myself is always not enough even if these were not my first.

The fieldwork of independent bookstore and querencia gave me joy of writing. My previous writing practice had been relatively conventional pattern but my writing changed to be creative and I was able to express about my perspectives and thoughts after two practices.

(Key sentences are in bold)

To summarize the above survey, 1 student out of 16 confessed of having a fun writing experience because of different format of writing from conventional self-introductory writing. Majority opinions on self-expressive writing studies stated that self-searching writing was possible based on self-narrative. Majority of the answers indicated that the book flap self-introductory writing from the independent bookstore fieldwork was helpful to think about one's future career and for self-visionary writing. It also indicated that a level of interest was increased when the querencia fieldwork overlapped the experience after independent bookstore fieldwork. Some answers stated that the writer could have 'a time to think about his or her self fully' and was 'helpful for self-expressive writing' from 'the motivation of future vision design.' Additionally, one answer stated that 'I experienced a connection between the keywords from media examples with ones I used in querencia and independent bookstore fieldwork while completing my writing for the last end of the semester project (creative career design). It was amazing. I definitely think that those 3 projects connected each other." It proved a key point where a relationship with the fieldworks and self-expressive writing amplified usefulness and voluntary writing.

The survey indicated that the students were able to focus on their own narratives when they configured the querencia space as an environment where they could do fieldworks by their selections in the pandemic situation to face their own narratives. In other words, if a plan of writing were organized to have time and space for a self-search by personal preference, it was possible to prepare the student 
to be focused for a self-expressive writing.

The indicated cases of this paper could be summarized as 'a method to achieve an education objective that is required by cognitive writing more effectively could be an expressionism perspective.' by YI Yang Sook[8] A self-expression is possible when one has a deep focus on one's issues. Most of the people try to convey thoughts and opinions by writing and $\mathrm{Z}$ generation has more desire on this trait than any other generations. It especially reveals a desire to promote and get recognized by others utilizing SNS platforms, even in the world of metaverse. KIM Nan Do indicates that 'it is one of the characteristics of $\mathrm{Z}$ generation and modern society that people reveals their multiple personas changing multiple masks' in his 'Trend Korea 2021' [9]. The class was configured utilizing the characteristics of $\mathrm{Z}$ generation so that the students were able to develop a writing from a self-formation process.

All students worked hard to write for their dreams. Below is an example by one of the student who wanted to be a member of National Forensic Service of Republic of Korea. The writing represented an eye-opening experience when an inner voice of the student became a reality after getting away from his or her needs for recognition by others from the class activities. It was a case that the fieldworks led to a positive self-expressive writing as this paper suggests.

[Table 4] A Creative Self-Vision Design Writing Example

\begin{abstract}
A book flap intro writing and the querencia fieldwork to overcome habitus were a process of self-awareness before looking at a big forest eventually. First, I thought about myself with a future career and how to appeal about myself in the course of book flap self-introduction. I especially tried to reveal my values in order to show my personal attractiveness in the author introduction. With this chain of work, I was able to think deep about my true objective of life, that is 'love,' beyond my concern on future career. Second, I thought about a must-have attitude for future progress after looking back on my negative habitus during the querencia fieldwork. My habitus was formed by my despair when I fell behind in competition during high school, and it made me fear new challenges by limiting by myself. But, I realized now that I needed to face an issue without any fear of failure. All class projects were my moment to look back not only at my inner forest and career path but more importantly the objective and direction of my life. And thus, based on this experience, I am trying to draw my vision as a researcher in National Forensic Service. It would be a process to see that forest that $I$ had never seen before expanding my inner forest.

(Key sentences are in bold by writer.)
\end{abstract}

\title{
4. Discussion
}

This paper is about a 'lived experience research' based on a case study of class activities which is utilized and focused in liberal arts studies as one of the qualitative phenomenology researches. A total of 142 students including 125 students in spring of 2019 and 17 students in summer semester in the 'Creative Thinking and Expression' class participated in a 4-week program that was designed to develop a self-expressive writing skills with fieldwork programs. This paper also aimed to verify the limitation of in-class writing activities as a college liberal arts writing class and to prove that the class design gave a positive impact on $\mathrm{Z}$ generation students by self-driven writing exercise such as self-vision designing and fieldworks in which was evidenced by class survey answers by the students. The liberal arts research is different from other researches such as education science, engineering or science disciplines. An accumulated data of actual field reports of class activities is vital in order to have a quantitative research result development with survey statistics. This paper is the first attempt without a precedent case to accumulate data of how the class supported the students in terms of development of new writing experience by the class design. Therefore, an upgraded methodology will be implemented and researched along with sustainable data gathering for acute analysis of student's writings of future classes. 


\section{Conclusions}

A journey of self-formation development is a process to complete the narrative of oneself through externalizing expertise of one's discipline during the university years. To support this, a writing class in liberal arts education needs to be multi-directional and multi-dimensional in order to fill the needs and demands from students in order to achieve the self-formation. The class was designed to fulfill the needs and demand of students by adding empirical experiences in the class to think about their future and to write a series of essays creatively through the process of self-learning and self-awareness.

Based on the survey and review of the study, the students felt an easy approach to writing after they experienced the first fieldwork to independent bookstore to select a book of their interests to benchmark. A self-search and self-learning was introduced and it positively initiated writing. A self-awareness was a key factor for the second fieldwork. The students learned how to find their true self dealing with querencia in order to write about themselves creatively for the readers. The class found that the students developed and organized future plans interlinked with previous assignments and they were able to express themselves objectively as the class progressed. In conclusion, it is important that the basic writing classes need to be re-designed in order to meet the demands of the students especially in pandemic situation with limited access to the campus. Self-learning and self-awareness had a strong impact to the students in order to motivate them to initiate writing and these were very much in line with the students of $Z$ generation. The fieldworks were a strong attraction to the students to register the class and 84 students out of 125 thought that the fieldworks motivated them to write. The study showed that expansion of fieldworks related to designing of creative writing class was necessary in order to have motivation, participation and proactive writing by the students. However, the students with no immediate objective and no interest of their disciplines had difficulties to navigate the progress of the class, and no motivation of self-learning and awareness was generated throughout the class. A solid guideline was necessary in order to interlink with 2 fieldworks assignment and the final project because the students without any advanced writing background had difficulty to develop to the final writing assignment from 2 initial writing assignments. Therefore, the expanded design of the fieldworks with solid connection to the course of self-searching and self-awareness is necessary for the students with no motivation and no immediate interest. The study was not able to distinguish the students with different disciplines so differentiated design application is necessary for science and engineering students from liberal arts students.

\section{References}

[1] Park Serin, Park Juhee, The Characteristics of Generation Z in the Creator Activities of Virgil Abloh, Journal of the Korean Society of Clothing and Textiles, (2021), Vol.45, No.2, pp.217-232, DOI: 10.5850/JKSCT.2021.45.2.217

[2] Bae SooHee, Han HaeRyon, Analysis of Lifestyle Shop Space Representation Characteristics for Generation MZ, KOREAN INSTITUTE OF INTERIOR DESIGN JOURNAL, (2021), Vol.30, No.2, pp.85-93.

[3] Ohmynews, http://www.ohmynews.com/NWS_Web/View/at_pg.aspx?CNTN_CD=A0002697653, Nov 30, (2020)

[4] Chung Kicheol, A Study on Methods of Feaching Creative Writing by Applying Life Experiences, The Journal of Literary Creative Writing, (2017), Vol.16, No.2, pp.101-131.

[5] Alfres North Whitehead, The Aims of education, (Translated from Oh Young Whan), Kungree Press, (2004), pp.1-322.

[6] Han Kyung Economy Dictionary, https://dic.hankyung.com/economy/list?word=\%EC $\% \mathrm{BC} \% 80 \% \mathrm{~EB} \% \mathrm{~A} \% \% 8 \mathrm{C} \% \mathrm{EC} \% 8 \mathrm{~B} \% 9 \mathrm{C} \% \mathrm{EC} \% 95 \% 84, \quad J u l \quad 13$ (2021) 
[7] Doris Martin, Habitus, (Translated by Bae Myungja), Dasan Chodang, (2020), pp.1-268, ISBN: 9791130631127

[8] Lee Yang Sook, A study on writing education using self-narrative, Korean Literary Theory and Criticism, (2011), Vol.15, No.1, pp.169-189, UCI: G704-000665.2011.15.1.009

[9] Kim nan-do, Jun Mi Yung, Choi JI hye, Lee Hyang Eun, Lee Jun Yung, Lee Su Jin, Seo Soo Hyeon, Kwon Jeong Yoon,
Han
$\mathrm{Da}$
Hye,
Trend
Korea
2021,
Miraeoichang,
(2020),

http://www.kyobobook.co.kr/product/detailViewKor.laf?mallGb=KOR\&ejkGb=KOR\&barcode=9788959896837 